\title{
Kajian Terhadap Sila Keadilan Dan Teori Keadilan Berfalsafah Libertarianisme Dari Sudut Pandang Berideologi Pancasila
}

\author{
Liana Endah Susanti
}

\author{
Dosen Ilmu Hukum, Universitas Soerjo, Jl. Cери Km.3, Ngawi, 63218 \\ E-mail: endahliana112@gmail.com
}

\begin{abstract}
Libertarianism is a classification of philosophy which considers freedom as the main perspective that must be honored. With this assumption making libertarianism is often seen as a processed result or new ideas as a more polite cover of anarchism. Libertarianism initiates a society with a minimal state role, as a manifestation of the fulfillment of rights and the creation of justice where the distribution of resources is determined by the ability of each individual through a market mechanism. With this, it is not impossible to cause a disintegration that will adversely affect their social life. Whereas on the other hand, the government, as it has been placed by libertarians, only acts as a stabilizer to monitor and ensure that there are no violations of rights that occur, not as an opening way towards the creation of a country's goals. Deeper, libertarians oppose various regulations and rules that smell of public interest as well as taxes because they are considered another form of covert slavery. This is said because for them, besides causing obligations that must be borne by each individual, government revenues will actually hinder the development and productivity of each individual. Various speculations, new arguments and terms emerge along with the development of ideological strata that claim that libertarians are as they understand them. Thus emerging new terms such as conservative, left-right, contemporary and so forth as a form of division of the libertarian camp. Based on this, it certainly makes them have their own characteristics in the placement of rights and the application of justice. Keywords : Libertarianis; Freedo; Rights and justice.
\end{abstract}

Abstrak

Libertarianisme merupakan klasifikasi filosofi yang menganggap kebebasan sebagai perspektif utama yang harus diagungkan. Dengan anggapan tersebut membuat libertarianisme kerap dipandang sebagai hasil olahan atau ide-ide baru sebagai cover yang lebih sopan dari anarkisme. Libertarianisme menggagas masyarakat dengan peran negara yang minimal,sebagai wujud dari pemenuhan hak dan terciptanya keadilan dimana distribusi sumber daya ditentukan oleh kemampuan masing-masing individu melalui mekanisme pasar. Dengan hal tersebut, bukan tidak mungkin akan menyebabkan terjadi suatu disintegrasi yang akan berdampak buruk bagi kehidupan sosial mereka. Sedangkan di sisi lain, pemerintah sebagaimana yang telah ditempatkan oleh kaum libertarian hanya berperan sebagai stabilisator untuk mengawasi dan memastikan tidak adanya pelanggaran hak yang terjadi, bukan sebagai pembuka jalan menuju terciptanya tujuan suatu negara. Lebih dalam lagi, libertarian menentang berbagai regulasi dan aturan yang berbau kepentingan publik seperti halnya pajak karena menganggap hal tersebut merupakan bentuk lain dari perbudakan terselubung. Dikatakan demikian karena bagi mereka selain mengakibatkan kewajiban yang harus menjadi tanggungan setiap individu, pendapatan pemerintah justru akan menghambat pembangunan dan produktivitas setiap individu. Berbagai spekulasi, argumentasi dan istilah baru bermuculan seiring dengan perkembangan strata ideologi yang saling mengklaim bahwa libertarian adalah sebagaimana yang mereka pahami. Sehingga muncul istilah-istilah baru seperti konservative, kiri-kanan, kontemporer dan lain sebagainya sebagai bentuk pembagian kubu libertarian. Berdasarkan hal tersebut tentunya membuat mereka memiliki karakteristik masing-masing dalam penempatan hak serta penerapan keadilan.

Kata Kunci : libertarianisme; kebebasan; hak dan keadilan.

\section{A. PENDAHULUAN}

\section{Latar Belakang}

Berbicara mengenai manusia, tentunya setiap manusia telah dikaruniai hak dari Tuhan sejak dilahirkan, baik hak asasi maupun hak yang tidak asasi. Berbagai hak tersebut diantaranya berupa hak untuk dicintai dan mendapat kasih sayang, mendapat pangan sandang dan papan dari orang tua, dan masih banyak lagi. Sementara hak yang bisa kita peroleh saat telah tumbuh dewasa salah satunya adalah kebebasan, yang mana bisa berupa kebebasan untuk menentukan jalan hidup, mengelola keuangan sendiri, dan lain sebagainya. Masih dalam konteks kebebasan, libertarianisme hadir sebagai falsafah yang mengagungkan kebebasan atas hak masingmasing individu. Falsafah yang tumbuh pada abad ke-17 dan mengalami puncak kejayaan pada abad ke-19 tersebut diciptakan berdasarkan atas asumsi bahwa kesempurnaan akal manusia mampu menciptakan konsep 
Website : http://yustisia.unmermadiun.ac.id/index.php/yustisia

kebenaran atas peran masing-masing individu. Untuk seorang libertarian kebebasan individu atau kepemilikan pribadi (self-ownership) sangat diperhitungkan, mengingat tidak setiap orang "berhak" untuk bekerja, memperoleh pendidikan, membayar pajak, mendapat jaminan kesehatan, mendapat perumahan yang layak atau beberapa hal lainnya, karena "hak" sebagaimana yang dimaksud adalah menyiratkan bahwa untuk memberikan hal-hal tersebut adalah bukan kewajibannya. Kaum libertarianisme menganggap jika seseorang dipaksa untuk mengorbankan dirinya bagi orang lain, itu bukan kebebasan melainkan perbudakan. Kebebasan disini berarti bahwa setiap orang memiliki hak untuk melakukan apa yang dia inginkan, bagaimana ia menjalani kehidupannya, dan untuk apa ia menggunakan hartanya, selama ia tidak mengganggu kehidupan dan milik orang lain. Perlu menjadi perhatian khusus memang, mengingat "hak" dan "keadilan" adalah opsi penting dalam kodratnya yang telah melekat dan dibutuhkan setiap individu. Untuk itulah perlu adanya titik terang yang mampu mempertegas letak hak dan keadilan dalam falsafah libertarian, agar dapat memahami sisi positif maupun negatifnya, sesuai dengan kacamata ideologi Pancasila khususnya sila yang berinstrumen keadilan di Indonesia. Berdasarkan hal tersebut, saya bermaksud untuk mengkaji lebih lanjut mengenai "KAJIAN TERHADAP SILA KEADILAN DAN TEORI KEADILAN BERFALSAFAH LIBERTARIANISME DARI SUDUT PANDANG BERIDEOLOGI PANCASILA".

\section{Rumusan Masalah}

1. Apakah yang menyebabkan timbulnya falsafah libertarianisme?

2. Bagaimana sikap libertarian terhadap kedudukan negara?

3. Bagaimanakah implementasi libertarianisme di negara-negara yang menganut falsafah tersebut?

4. Bagaimanakah kajian sila keadilan dan teori keadilan berfalsafah libertarianisme dari sudut pandang berideologi Pancasila?

\section{Tujuan}

Kajian ini bermaksud menyajikan informasi mengenai libertarianisme dalam kaitan hak serta keadilan yang dikemas berdasarkan kacamata sila keadilan dan teori keadilan, agar partisipan mampu berfikir kritis mengenai implementasi paham libertarianisme sehingga mampu mengolah sisi negatif maupun positif dari bahan kajian tersebut.

\section{Metode Kajian}

Dalam melakukan kajian lebih lanjut tentang sesuatu, metode kajian adalah hal penting untuk menjawab rumusan-rumusan masalah yang telah disusun dengan tepat dan akurat.

Metode berasal dari Bahasa Yunani "Methodos" yang berarti cara atau jalan yang ditempuh. Sehubungan dengan upaya ilmiah, maka metode menyangkut masalah cara kerja untuk dapat memahami objek yang menjadi sasaran ilmu yang bersangkutan. Dan fungsi metode berarti sebagai alat untuk mencapai tujuan yang hendak disajikan oleh pengkaji.

Metode yang digunakan pada kajian kali ini adalah metode kualitatif dengan menghadirkan realitas sosial dan berbagai fenomena yang menyertainya. Pengembangan teori dilakukan secara empiris yang berpijak pada sifat kontekstual dan historis. Metode kualitatif yang digunakan memungkinkan kajian ini untuk lebih mudah dipahami karena mengacu pada sajian yang digambarkan secara deskriptif. Yang mana deskriptif disini diasumsikan sebagai penggambaran, keadaan, situasi, kondisi, karakteristik dan segala seluk-beluk obyek yang dikaji dengan detail dan fakta yang terjadi. Sedangkan data yang digunakan disini merupakan data sekunder yaitu data yang mengacu pada informasi yang telah tersedia sebelumnya, misalnya catatan atau dokumentasi perusahaan, publikasi pemerintah, analisis industri oleh media, situs Web, internet dan sebagainya.

\section{B. TINJAUAN PUSTAKA}

\section{Libertarianisme}

Libertarianisme berasal dari bahasa Latin liber, yang artinya bebas adalah klasifikasi filosofi politik yang menjunjung tinggi kebebasan sebagai fokus utama mereka dan sebagai tujuan. Mereka berusaha untuk memaksimalkan otonomi dan kebebasan memilih, menekankan kebebasan politik, asosiasi sukarela dan keutamaan penilaian individu. ${ }^{1}$

Pada dasarnya paham libertarianisme mengusung kebebasan (liberty) sebagai nilai utamanya.Yang dimaksud pada hal ini adalah situasi setiap orang yang memliki kuasa penuh atas dirinya dan segala yang dihasilkannya (self ownership \& property ownership). Hak-hak alamiah seseorang sama sekali tidak boleh dilanggar oleh siapapun dan negara hanya bertugas memastikan kebebasan serta menjamin tidak ada

\footnotetext{
${ }^{1}$ Woodcock, George (2004). Anarchism: A History Of Libertarian Ideas And Movements. Peterborough, Ont.: Broadview Press. hlm. 16
} 
Website : http://yustisia.unmermadiun.ac.id/index.php/yustisia

pelanggaran atas hak masing-masing orang melalui penegakan hukum dan sistem peradilan. Libertariansisme merupakan neologi dari liberalisme klasik, serta mengandung dua obyek penting dalam implementasinya yaitu negara minimal dan pasar bebas.

Yang dimaksud negara minimal disini adalah bahwa negara tidak berhak menggunakan kekuasaan tunggalnya untuk mencampuri hubungan antarwarganya dan menganggap satu-satunya tugas negara adalah melindungi kontrak antara individu dan kepemilikan swasta melalui sistem pengadilan dan penegakan hukum. Sehingga dapat dikatakan bahwa suatu negara disebut sebagai negara minimal apabila memenuhi beberapa indikasi seperti :

1.Negara hanya berperan untuk menjaga agar tindak kejahatan tidak terjadi;

2.Negara tidak boleh ikut campur dalam redistribusi pendapatan;

3.Negara hanya boleh menegakkan kesepakatan atas dasar sukarela;

4.Peran pemerintah yang terlalu jauh dalam pemerataan pendapatan dianggap sebagai bentuk perbudakan terselubung;

5.Pemberlakuan pajak dianggap sebagai diskriminasi hak individu;

6.Negara hanya bertugas memastikan kebebasan bahwa keadilan dalam konteks kebebasan, tidak disalahgunakan untuk merugikan orang lain.

Sedangkan pasar bebas yang diasumsikan disini merupakan kondisi dimana seluruh transaksi bebas dan keputusan ekonomi maupun aksi yang berhubungan dengan uang, barang, dan jasa adalah sukarela di mana seluruh keputusan ekonomi dan aksi oleh individu yang berhubungan dengan uang, barang, dan jasa adalah suatu hal yang bebas bagi setiap individu, bahkan untuk saling menjatuhkan satu sama lain. Poin penting dari pemberlakuan pasar bebas di suatu negara adalah apabila:

1.Mekanisme pasar bekerja sebebas mungkin;

2.Transaksi terjadi atas dasar sukarela;

3.Persaingan dan saling menjatuhkan adalah suatu kewajaran yang diperbolehkan;

4.Intervensi minimum pemerintah dalam segala sektor pasar.

Atribut "klasik" pada liberalisme-libertarian menegaskan posisi libertarianisme sebagai pembela kebebasan pada satu sisi, tetapi, pada sisi lain, membedakannya dari liberalisme yang dikenal secara luas, khususnya dalam konteks politik Amerika Serikat (AS) kontemporer. Kaum libertarian mengidentifikasi diri sebagai penerus liberalisme yang tercermin dalam dua konsep utama, yaitu "negara minimal" dalam filsafat politik John Locke (1632-1704) dan "kapitalisme pasar bebas" dalam teori ekonomi Adam Smith (1723-1790). ${ }^{2}$

Selain itu,dari sudut pandang kaum libertarian, kebebasan (liberty) adalah sesuatu yang harus diimplementasikan. Kebebasan merupakan situasi tanpa-agresi dalam relasi interpersonal. Terdapat banyak bentuk relasi interpersonal, yang mana "pasar" adalah satu di antaranya. Murray Rothbard, For a New Liberty: The Libertarian Manifesto . Banyak libertarian mengkritik perspektif dalam pemetaan filsafat politik kontemporer, karena istilah-istilah yang lazim digunakan didalamnya memiliki makna yang cenderung tumpang tindih dalam realitas kontemporer misalnya : konservatif, liberal, kiri kanan dan lain sebagainya. Hal ini jelas berbeda dengan orientasi politik libertarian yang hanya menitikberatkan kekuasaan dan kebebasan secara mutlak tanpa embel-embel yang kurang berguna. Sejalan dengan kutipan menarik dari David Boaz yang jika diartikan dalam bahasa Indonesia kurang lebih memiliki arti sebagai berikut :

“ konservatif (liberal) ingin jadi ayahmu, memberitahumu apa yang harus dan apa yang tak boleh kau lakukan. Liberal ingin jadi ibumu, memberimu makan, menyelimutimu dan membersihkan hidungmu. Libertarian ingin menjadikanmu sebagai orang dewasa"

Prinsip utama libertarianisme adalah "hidup dan biarkan hidup". Istilah ini pertama kali digunakan menjelang akhir abad ke-18 dalam debat yang mengguncang kehendak bebas terhadap determinisme. ${ }^{3}$

Tanpa disadari libertarian secara implisit merupakan bentuk baru atau cover yang lebih sopan dari anarkisme. Petr Arshinov yang menyebut dirinya anggota kelompok anarkis Rusia pernah menyatakan dalam "Platform Organisasi Komunis Libertarian". Bahwa dalam paham yang dianut oleh libertarian, kontradiksi antara hal positif dan kandungan ide-ide libertarian tak terbantahkan,serta keadaan menyedihkan dimana gerakan anarkis tumbuh, memiliki penjelasan dalam bermacam sebab, dari itu semua yang terpenting adalah cara penanggulangan dari ketiadaan prinsip-prinsip dan praktek organisasi dalam gerakan anarkis. Meski demikian tak diragukan lagi bahwa keadaan disorganisasi ini diturunkan dari teori yang kurang baik. Terutama dari penerjemahan yang keliru atas prinsip-prinsip individualitas dalam anarkisme, teori ini telah sering kali disalahtafsirkan dengan ketiadaan segala tanggungjawab. Kaum yang suka menekankan soal "ke-diri-an", melulu dengan pandangan terhadap kesenangan pribadi. Terus-menerus melekat rapat-rapat pada kondisi kacau

\footnotetext{
${ }^{2}$ David Boaz, Libertarianism: A Primer, pp. 36-40.

${ }^{3} \mathrm{https}$ ///www.economist.com/johnson/2010/10/08/the-isms-of-the-week-liberalism-and-libertarianis

${ }^{4} \mathrm{https} / / / \mathrm{www}$.anarkismo.net/article/930
} 
Website : http://yustisia.unmermadiun.ac.id/index.php/yustisia

gerakan anarkis, dan dalam pembelaannya berusaha mengacu pada prinsip-prinsip mendasar anarkisme dan teoritisi masa lalu.

\section{Keadilan}

Keadilan adalah kondisi kebenaran ideal secara moral mengenai sesuatu hal, baik menyangkut benda atau orang. Menurut sebagian besar teori, keadilan memiliki tingkat kepentingan yang besar. John Rawls, filsuf Amerika Serikat yang dianggap salah satu filsuf politik terkemuka abad ke-20, menyatakan bahwa "Keadilan adalah kelebihan (virtue) pertama dari institusi sosial, sebagaimana halnya kebenaran pada sistem pemikiran". 5 Sementara itu,banyak argumen yang menyatakan bahwa keadilan merupakan situasi dan kondisi yang hadir atas keselarasan dan terpenuhinya hak serta kewajiban sebagai tindak lanjut dari prinsip meletakkan semua pada tempatnya.

Keadilan sendiri berasal dari istilah adil yang berasal dari bahasa Arab. Kata adil berarti tengah, adapun pengertian adil adalah memberikan apa saja sesuai dengan haknya. Keadilan berarti tidak berat sebelah, menempatkan sesuatu ditengah-tengah, tidak memihak, berpihak kepada yang benar, tidak sewenang-wenang. Keadilan juga memiliki pengertian lain yaitu suatu keadaan dalam kehidupan masyarakat, berbangsa dan bernegara memperoleh apa yang menjadi haknya sehingga dapat melaksanakan kewajibannya. Sedangkan Pengertian Keadilan Menurut Kamus Bahasa Indonesia (KBBI) adalah suatu hal yang tidak berat sebelah atau tidak memihak serta tidak sewenang-wenang. Menurut kamus besar bahasa Indonesia (KBBI) kata adil berasal dari kata adil, yang memiliki arti kejujuran, kelurusan dan keikhlasan yang tidak berat sebelah.

a. Definisi Keadilan Menurut Para Ahli

1.Aristoteles

Yang mengatakan bahwa keadilan adalah tindakan yang terletak diantara memberikan terlalu banyak dan sedikit yang dapat diartikan memberikan sesuatu kepada setiap orang sesuai dengan apa yang menjadi haknya.

2.Frans Magnis Suseno

Menyatakan pendapatnya tentang pengertian keadilan adalah keadaan antarmanusia yang diperlakukan dengan sama sesuai dengan hak dan kewajibannya masing-masing.

\section{Notonegoro}

Berpendapat bahwa keadilan adalah suatu keadaan dikatakan adil jika sesuai dengan ketentuan hukum yang berlaku.

4.Thomas Hubbes

Yang mengatakan bahwa pengertian keadilan adalah sesuatu perbuatan dikatakan adil apabila telah didasarkan pada perjanjian yang telah disepakati.

5.Plato

Menyatakan bahwa pengertian keadilan adalah diluar kemampuan manusia biasa dimana keadilan hanya dapat ada di dalam hukum dan perundang-undangan yang dibuat oleh para ahli yang khususnya memikirkan hal itu.

6.W.J.S Poerwadarminto

Mengatakan bahwa pengertian keadilan adalah tidak berat sebelah, sepatutnya tidak sewenangwenang.

7.Imam Al-Khasim

Adalah mengambil hak dari orang yang wajib memberikannya dan memberikannya kepada orang yang berhak menerimanya.

b. $\quad$ Macam-macam keadilan secara umum dapat diklasifikasian sebagai berikut: ${ }^{7}$

1.Keadilan Komunikatif (Iustitia Communicativa)

Pengertian keadilan komunikatif adalah keadilan yang memberikan kepada setiap orang terhadap apa yang menjadi bagiannya dengan berdasarkan hak seseorang pada suatu objek tertentu. Contoh keadilan ini adalah Iwan membeli tas Andri yang harganya 100 ribu maka Iwan membayar 100 ribu juga seperti yang telah disepakati. Keadilan yang memberikan kepada masing-masing terhadap apa yang menjadi hak pada suatu subjek hak yaitu individu. Keadilan distributif adalah keadilan yang menilai dari proporsionalitas atau kesebandingan berdasarkan jasa, kebutuhan, dan kecakapan. Contohnya adalah karyawan yang telah bekerja selama 30 tahun, maka ia pantas mendapatkan kenaikan jabatan atau pangkat.

2.Keadilan Legal (Iustitia Legalis)

\footnotetext{
${ }^{5}$ John Rawls, A Theory of Justice (revised edn, Oxford: OUP, 1999), p.

${ }^{6} \mathrm{https}: / / \mathrm{www} . z o n a r e f e r e n s i . c o m /$ pengertian-keadilan

${ }^{7} \mathrm{http} / / /$ www.artikelsiana.com/2015/01/pengertian-keadilan-macam-macam-keadilan.htm
} 
Website : http://yustisia.unmermadiun.ac.id/index.php/yustisia

Pengertian keadilan legal adalah keadilan menurut undang-undang dimana objeknya adalah masyarakat yang dilindungi UU untuk kebaikan bersama atau banum commune. Contoh keadilan legal adalah Semua pengendara wajib mentaati rambu-rambu lalu lintas.

3.Keadilan Vindikatif (Iustitia Vindicativa)

Pengertian keadilan vindikatif adalah keadilan yang memberikan hukuman atau denda sesuai dengan pelanggaran atau kejatahannya. Contoh keadilan vindikatif adalah pengedar narkoba pantas dihukum dengan seberat-beratnya.

4.Keadilan Kreatif (Iustitia Creativa)

Pengertian keadilan kreatif adalah keadilan yang memberikan masing-masing orang berdasarkan bagiannya yang berupa kebebasan untuk menciptakan kreativitas yang dimilikinya pada berbagai bidang kehidupan. Contoh keadilan kreatif adalah penyair diberikan kebebasan dalam menulis, bersyair tanpa intervensi atau tekanan apapun.

5.Keadilan Protektif (Iustitia Protektiva)

Pengertian keadilan protektif adalah keadilan dengan memberikan penjagaan atau perlindungan kepada pribadi-pribadi dari tindak sewenang-wenang oleh pihak lain. Contoh keadilan protektif adalah Polisi wajib menjaga masyarakat dari para penjahat.

\section{c. Keadilan Berideologi Pancasila}

Keadilan Sosial memiliki makna yang sangat luas. Makna dari sila ke-5 ada pada butir-butir implementasi Pancasila yang tertera pada ketetapan MPR No. I/MPR/ $2003^{8}$ yaitu sebagai berikut:

1.Mengembangkan perbuatan yang luhur, yang mencerminkan sikap dan suasana kekeluargaan dan kegotongroyongan.

Pada butir ini dijelaskan bahwa warga Indonesia hendaknya berperilaku baik dan berbudi luhur misalnya dengan saling peduli, membantu, bergotong royong, juga bersikap tenggang rasa terhadap sesama tanpa membedakan pangkat, derajat, pekerjaan, suku,ras dan agama sehingga terbentunya kehidupan bermasyarakat yang sejahtera dan damai, tanpa adanya diskriminasi.

2.Mengembangkan sikap adil terhadap sesama.

Adil terhadap sesama maksudnya adalah memberikan perlakuan yang sama kepada seluruh warga tanpa membedakan berbagai faktor misalnya suku, ras, agama, dan pekerjaan. Semua rakyat Indonesia memiliki kedudukan sama dihadapan hukum.

3.Menjaga keseimbangan antara hak dan kewajiban.

Harus ada keseimbangan antara hak dan kewajiban yang didapatkan oleh rakyat Indonesia. Rakyat Indonesia tidak boleh hanya menuntut haknya saja, kewajiban dari setiap individupun harus dilaksanakan.

4.Menghormati hak orang lain

Setiap manusia memiliki hak, bahkan hak tersebut ada yang diperoleh sejak lahir yang juga disebut sebagai Hak Asasi Manusia. Setiap manusia harus saling menghormati hak orang lain misalnya dengan sikap saling menghargai terhadap perbedaan satu individu dengan individu lainnya.

5.Suka memberi pertolongan kepada orang lain agar dapat berdiri sendiri.

Manusia adalah makhluk sosial yang artinya tidak dapat hidup sendiri tanpa adanya bantuan dari orang lain. Setiap manusia harus saling tolong menolong terhadap sesamanya agar mencapai kehidupan yang sejahtera.

6.Tidak menggunakan hak milik untuk usaha-usaha yang bersifat pemerasan terhadap orang lain

7.Saat ini kasus suap, pungli, dan sogok menyogok masih banyak terjadi. Hal-hal tersebut bersifat 'memeras' dan sangat merugikan bagi orang lain. Tidak menggunakan hak milik untuk hal-hal yang bersifat pemborosan dan gaya hidup mewah.

Pada butir ini dimaksudkan agar rakyat Indonesia menjauhi pemborosan atau pemakaian uang, barang dan sumber daya secara berlebihan.

8.Tidak menggunakan hak milik untuk hal yang bertentangan dengan atau merugikan kepentingan umum.

Korupsi merupakan salah satu perbuatan yang sangat merugikan baik merugikan negara maupun orang lain karena hak orang lain diambil oleh si koruptor teresebut. Hal yang mendasari terjadinya korupsi adalah dikesampingkannya kepentingan umum. Sebaiknya manusia lebih mempriorotaskan kepentingan umum diatas kepentingan pribadi.

9.Suka bekerja keras

Kerja keras adalah usaha yang dilakukan sesorang dalam mengupayakan suatu tujuan yang ia buat. Kerja keras merupakan hal yang sangat baik dan hendaknya dilakukan dengan benar dan tidak melanggar hukum.

\footnotetext{
${ }^{8}$ https://jagad.id/pengertian-keadilan-sosial-makna-dan-contohnya
} 
Website : http://yustisia.unmermadiun.ac.id/index.php/yustisia

10. Suka meghargai hasil karya orang lain yang bermanfaat bagi kemajuan dan kesejahteraan bersama. Indonesia dipenuhi dengan warganya yang berbakat dalam berkarya dalam segala bidang. Hendaknya kita dapat menghargai karya dan prestasi anak bangsa demi kemajuan dan kesejahteraan Indonesia. Karena tak sedikit warga Indonesia yang berprestasi namun tidak dihargai oleh bangsanya sendiri.

11. Suka melakukan kegiatan dalam rangka mewujudkan kemajuan yang merata dan berkeadilan sosial. Kesenjangan sosial masih banyak ditemukan di negeri ini. Oleh sebab itu perlunya pemerataan dari segala bidang agar terwujudnya Indonesia yang sejahtera secara merata misalnya dengan kegiatan pengabdian sosial yang dilakukan oleh dokter dan guru di pelosok-pelosok Indonesia.

\section{PEMBAHASAN}

\section{Sebab Timbulnya Falsafah Libertarianisme}

Dalam diskusi gerakan sosial, makna libertarian kerap dipadankan dengan kebebasan bersaing ala pasar bebas. Bila merujuk penggunaannya pertama kali, pemaknaan tersebut adalah bentuk sesat pikir. Istilah libertarian tidaklah lahir dari semangat kompetisi, melainkan kritik atas sentralisasi ekonomi dan politik, untuk mengembalikan semangat gerakan sosial yang kurang beradap serta mengadopsi pola-pola sentralistik kapitalisme dan negara.

Istilah libertarian dalam gerakan radikal diperkenalkan pertama kali di tahun 1858 oleh seorang anarkis berkebangsaan Perancis, Joseph Déjacque, melalui jurnal gerakan sosial Le Libertaire di New York. Di tahun 1880 istilah tersebut kemudian diadopsi dalam Kongres Anarkis Perancis, menjadi komunisme libertarian atau sosialisme libertarian. Salah satu alasan-nya adalah untuk menghindari politik represif anti-anarkis di dataran Eropa saat itu. Barulah pada tahun 80-an, partai sayap Kanan di Amerika mulai mengadopsi dan mendistorsi istilah libertarian untuk menggambarkan politik free market capitalism mereka. Ironisnya, kebanyakan intelektual Kiri di Indonesia juga ikut-ikutan dalam sesat pikir ini.

Sekarang, tepat 157 tahun kemunculan istilah "libertarian", tulisan ini bisa jadi upaya tersendiri untuk mengembalikan akar libertarian pada posisinya. Istilah Kanan dan Kiri tidak relevan membedakan antara yang pro-pasar bebas dan pro-kebebasan sejati. Jika bukan libertarian, maka ia adalah non-libertarian. Menautkan tema libertarian di belakang istilah sosialisme menunjukkan keliyanan sosialisme yang dimaksudkan. Sosialis libertarian menolak gagasan dalam sosialisme otoritarian mengenai kepemilikan dan kontrol negara atas ekonomi, sekaligus menolak negara itu sendiri. Tatanan sosialis berarti kendali atas alat produksi sepenuhnya berada langsung di tangan kelas pekerja, bukan negara, bukan pula yang mengatasnamakan kelas pekerja. Dan kendali tersebut haruslah merupakan usaha dari kelas pekerja itu sendiri.

Perihal perbedaan antara sosialis libertarian dengan sosialis otoritarian, anarkis Italia yang dihukum mati pemerintah Amerika Serikat, Vanzetti Bartolomeo ${ }^{9}$, menuliskan hal itu secara ringkas dan tanpa basa-basi, "Kita semua adalah sosialis, begitu juga kaum sosial-demokrat, kaum sosialis, komunis, dan IWW (kependekan dari Industrial Woekers of The World, yang merupakan sebuah serikat sindikalis buruh internasional), mereka semua adalah sosialis. Yang membedakan kami dari mereka dan ini adalah hal mendasar, bahwa mereka otoriter sementara kami libertarian, mereka percaya akan negara atau pemerintahnya, kami tak percaya negara atau pemerintah apapun".

\section{Sikap Libertarian Terhadap Kedudukan Negara}

Sebelum membahas jawaban permasalahan diatas ada baiknya kita mengetahui dahulu apa yang dimaksud dengan negara. Menurut KBBI negara adalah kelompok sosial yang menduduki wilayah atau daerah tertentu yang diorganisasi di bawah lembaga politik dan pemerintah yang efektif, mempunyai kesatuan politik dan berdaulat sehingga berhak menentukan tujuan nasionalnya.

Pada umumnya sebuah negara memiliki kekuasaan yang efektif, memaksa serta mengikat, hal tersebut diimplementasikan melalui aturan-aturan atau larangan yang konstitusional yaitu "hukum" serta akan memberi sanksi atas pelanggaran yang dilakukan. Namun ada sebagian orang yang beranggapan bahwa hukum tidak seharusnya mencampuri kehidupan sosial seorang individu dan lebih mendukung negara terbatas untuk melindungi hak-hak individu dari agresi pihak lain. Hal itulah yang dianut oleh paham libertarianisme dimana mereka menentang adanya pemaksaan, kesewenang-wenangan,dan berbagai aturan yang mengharuskan mereka melakukan apa yang menjadi tujuan negara. Diantara penggagas-penggagas teori libertarianisme Nozick adalah salah satu yang dianggap kontroversial dalam sepak terjangnya membuka pemahaman-pemahaman baru dalam lingkung libertarianisme. Dalam karangannya yang berjudul “ Anarchy, State dan Utopia” (1974) Nozick mengkritisi kaum anarkis yang menolak eksistensi negara, dan juga menguraikan secara panjang lebar pandangannya tentang hak-hak individu sebagai basis bagi keadilan.

\footnotetext{
${ }^{9}$ https://perhimpunanmerdeka.wordpress.com/2015/06/15/mengusulkan-sosialisme-libertarian/
} 


\section{Website : http://yustisia.unmermadiun.ac.id/index.php/yustisia}

Libertarian berkeyakinan bahwa pemerintah merupakan pemegang kendali kehidupan masyarakat maka akan terjadi diskriminasi hak. Karena jika hukum dan aturan yang berlaku disamaratakan, belum tentu hukum tersebut mampu memberikan keadilan bagi setiap sudut masyarakat. Pasalnya, setiap individu memiliki kebutuhan akan keadilan yang berbeda-beda, adil bagi seseorang,belum tentu adil bagi orang lainnya. Hal ini berkaitan dengan teori partisipasi yang dikemukakan oleh Nozick, yang paling menarik adalah argumennya tentang pasrtisipasi yang kurang lebih berisi :"andai koloni kutu hidup di tanduk seekor rusa, apakah para kutu berhak untuk memaksa si rusa untuk tidak menyebrang sungai untuk mencari makan?” Menurut Nozick jawabannya adalah tidak karena setiap makhluk mempunyai kendali atas segala yang menyangkut kehidupannya.

Begitu pula bagi penganut paham libertarianisme, mereka menganggap bahwa setiap individu memiliki hak dan kebebasan penuh untuk mengkontrol segala sesuatu yang berhubungan dengan kehidupan mereka. Libertarian tidak mengakui peran negara sebagai pendikte arah dan tujuan hidup dengan segala aturan dan perangkatnya, namun mereka mendukung peran "negara minimal" dimana negara hanya bertugas memastikan keadilan tidak disalahgunakan dan tidak merugikan pihak lain, serta hak mampu terdistribusikan dengan baik tanpa adanya kerumpangan melalui : penegakan hukum dan sistem peradilan. Dengan begitu masyarakat mampu bertransformasi dan berlomba-lomba untuk berkembang dan tidak tertinggal sebagai bentuk dari persaingan bebas. Keharusan membayar sejumlah biaya kepada pemerintah seperti halnya pajak untuk didistribusikan kepada kaum yang membutuhkan akan terlalu memanjakan masyarakat yang menerima dan mengakibatkan perbudakan ekonomi bagi mereka yang diharuskan membayar. Selain itu menurut Nozick, memperkuat peran negara atas alasan menghalangi penyalahgunaan kewenangannya adalah "strategi buruk" karena membuat para pemburu rente semakin tergiur untuk memanfaatkan potensi kewenangan yang dimiliki para pejabat negara. ${ }^{10}$

Nozick mengungkapkan perbedaan secara fundamental terlihat dengan jelas antara kaum anarkis dengan kaum libertarian, mengenai sikap mereka terhadap eksistensi negara. Kaum anarkis menolak eksistensi negara dengan alasan negara mengurung serta membelenggu kebebasan. Sedangkan libertarian, sebagaimana mengingat pemahaman dari Nozick adalah menerima negara yang memiliki peran sebagai stabilisator serta mekanisme bersama untuk melindungi kebebasan itu sendiri. Dengan memposisikan keadilan dengan terpenuhinya hak, dengan hak-hak individu merupakan basis utamanya, manusia akan mencari cara untuk mempertahankan hak individunya, dan salah satu cara yang paling logis adalah bergabung dengan individu lain sehingga terciptalah suatu asosiasi walau hal ini tanpa terencana sebelumnya. Asosiasi inilah yang akhirnya berperan untuk menjaga hak para anggotanya agar tidak dilanggar. Dan lebih lanjut lagi, asosiasi ini bukan tidak mungkin akan membentuk peran barunya yaitu monopoli kekerasan atas nama penegakan hak dan redistribusi hak secara setara bagi semua warga. Inilah "negara minimal" sebagaimana yang dimaksud Nozick. ${ }^{11}$

\section{Implementasi Negara-Negara Yang Menganut Falsafah Libertarianisme}

Libertarianisme merupakan sebuah gagasan yang mengakui bahwa individu merupakan subjek yang otonom, dan merupakan unit terkecil dalam masyarakat. Seperti yang telah dibahas sebelumnya, libertarianisme mengakui bahwa setiap individu memiliki gagasan yang berbeda-beda mengenai gaya hidup. Pengakuan terhadap otonomi individu bukan lantas berarti sama dengan menyatakan bahwa identitas seseorang merupakan sesuatu yang tidak ada. Bahwa setiap individu memiliki identitasnya masing-masing adalah fakta sosial yang tidak bisa dibantah. ${ }^{12}$ diantaranya :

Kehidupan libertarian kurang lebih terdefinisikan sebagaimana telah dikemukakan oleh para ahli ${ }^{13}$

1.David Boaz dalam Liberalism : A Primer oleh David Boaz, Free Press, 1997 yaitu :

"Libertarianisme adalah pandangan bahwa setiap orang memiliki hak untuk menjalani hidupnya dengan cara apa pun yang ia pilih selama ia menghormati hak setara orang lain. Libertarian mempertahankan hak setiap orang untuk hidup, kebebasan, dan hak milik yang dimiliki orang secara alami, sebelum pemerintah diciptakan. Dalam pandangan libertarian, semua hubungan manusiaharus bersifat sukarela; satu- satunya tindakan yang harus dilarang oleh hukum adalah tindakan yang melibatkan inisiasi kekuatan terhadap mereka yang tidak melakukan tindakan kekerasan seperti pembunuhan, pemerkosaan,perampokan, penculikan, dan penipuan."

2.Tantangan Demokrasi (edisi ke-6), oleh Kenneth Janda, Jeffrey Berry, dan Jerry Goldman:

"Kaum liberal mendukung tindakan pemerintah untuk mempromosikan kesetaraan, sedangkan kaum konservatif mendukung tindakan pemerintah untuk mempromosikan ketertiban. Libertarian

\footnotetext{
${ }^{10}$ https://indeks.or.id/2016/12/09/libertarianisme-kebebasan-hak-dan-keadilan

${ }^{11}$ Robert Nozick, Anarchy, State, and Utopia, p. 113.

${ }^{12}$ http://indri-darwis.blogspot.com/2011/11/konsep-keadilan.html

${ }^{13} \mathrm{https}$ ///theihs.org/who-we-are/what-is-libertarian/
} 
Website : http://yustisia.unmermadiun.ac.id/index.php/yustisia

mendukung kebebasan dan menentang tindakan pemerintah untuk mempromosikan kesetaraan atau ketertiban."

3.The Machinery of Freedom oleh David Friedman, Open Court Publishing Company, 1973

"Ide sentral dari libertarianisme adalah bahwa orang harus diizinkan untuk menjalankan kehidupan mereka sendiri sesuai keinginan mereka."

Singkat cerita, libertarian hidup dengan cara mereka sendiri,sesuai dengan kemauan mereka sendiri, dengan pandangan hidup terhadap masyarakat yang bersifat suka rela dan seperlunya, selama hal tersebut mereka anggap tidak mengakibatkan pelanggaran hak untuk orang lain dengan meminimalkan peran pemerintah dan memaksimalkan kebebasan setiap individu.

Fakta sosial yang hadir mengenai para penganut paham ini memberikan contoh kongkrit tentang cara mereka hidup, antara lain yaitu tentang ketidakmauan mereka untuk ikut bertanggung jawab atas kaum yang kurang mampu atau membutuhkan. Karena mereka menganggap apa yang telah mereka miliki adalah hasil dari apa yang mereka usahakan ketercapaiannya. Dan bukan untuk semata-mata dihamburkan bagi mereka yang tidak mau bekerja keras. Dengan dasar anggapan tersebutlah para libertarian menolak adanya kewajiban yang bersifat sosial seperti pembayaran pajak, atau program pembiayaan bagi orang yang kurang beruntung dan subsidi. Itu berarti bahwa libertarian tidak mengharuskan orang lain menerima atas apa yang dimiliki orang lain, dan mereka juga berkeyakinan bahwa pemerintah tidak "berhak" memaksa mereka untuk membantu orang lain walaupun itu beralasan menyamaratakan keadilan sosial.

Berbagai sikap yang dimiliki libertarian tersebut kerap kali menuai kritik dan pro-konta. Pasalnya sikap tersebut kerap dianggap sebagai cerminan "keegoisan" dari dasar anarkisme yang digadang-gandang sebagai nenek moyang libertarianisme. Terlepas dari segala kontroversi yang timbul, umat manusia dibelahan dunia manapun memang memiliki berbagai hak dan kewajiban. Perihal tersebut memang perlu diperhatikan pengelolaanya, baik dari segi regulasi aturan hingga segala perangkat serta sarana dan prasarananya. Dengan apapun falsafah yang dianut, dengan ataupun tanpa, bahkan memiliki ataupun tidak, tujuan negara demi menciptakan keadilan sosial.

\section{Kajian Sila Keadilan Dan Teori Keadilan Berfalsafah Libertarianisme Dari Sudut Pandang Berideologi Pancasila}

Menurut Aristoteles "justice” atau keadilan yaitu " memberikan apa yang layak baginya". Sedangkan keadilan dalam ranah libertarianisme adalah keadilan yang didasarkan pada pengakuan atas hak-hak individu atau interpersonal liberty dimana kebebasan seseorang dibatasi oleh kebebasan orang lain. Kutipan menarik dari Nozick : "hak bukan suatu tujuan yang harus direalisasikan oleh suatu tatanan sosial, tetapi aksioma dari tatanan sosial yang harus bersifat aktif dan mengekang berbagai bentuk tindakan yang hendak melanggarnya". Anggapan ini memiliki arti bahwa tujuan sebagai pendekatan secara normatif bukan hal yang tepat,justru kekangan adalah sesuatu yang akan memukul mundur terjadinya tindakan pelanggaran hak. Sisi lainnya yaitu perihal menentang "keadilan distributif" karena ia menganggap keadilan bukan suatu hal yang dapat dikaitkan dengan konteks "mekanisme" yang merupakan suatu proses dari pembagian yang berporos pada sentralisasi. Keadilan sebagaimana yang digaungkan Nozick merupakan milik individu secara alami, dan masing-masing pemilik bebas mengontrolnya. Namun bebas disini harus didasarkan pada tiga prinsip penting:

1. Asal-usul kepemilikan (original aequisition of holdings)

2. Peralihan kepemilikan (transfer of holding)

3. Pembetulan atas ketidakadilan atau pelanggaran atas prinsip 1 dan 2 (rectification of injustice)

Berdasarkan prinsip tersebut, Nozick merumuskan keadilan transitif evaluatif. Dikatakan demikian,karena transitif merupakan istilah untuk kesesuaian antara situasi yang adil berasal dari cara perolehan yang adil pula. Sedangkan kata evaluatif dipakai karena kadilan sendiri merupakan bahan historis yang merupakan sejarah dan bagaimana keadilan yang diharapkan mampu diperoleh. Maka dari itu muncul gagasan barunya yang membagi perolehan hak menjadi hak terpola dan hak tidak terpola. Ilustrasi yang terkenal dari seorang Nozick mengenai teori tersebut adalah tentang pemain basket dan enterpreneur mesin. ${ }^{14}$

Lalu bagaimana pandangan keadilan menurut teori para ahli dan Indonesia yang berideologi Pancasila mengenai keadilan dalam falsafah libertarian? Jhon Rawls berpendapat bahwa keadilan adalah kebajikan utama dari hadirnya institusi-institusi sosial atau social institutions. Akan tetapi, menurutnya, kebaikan bagi seluruh masyarakat tidak dapat mengesampingkan atau mengganggu rasa keadilan dari setiap orang yang telah memperoleh rasa keadilan, khususnya masyarakat lemah.

Oleh karena itu, sebagian kalangan menilai cara pandang Rawls sebagai perspektif "liberal-egalitarian of social justice". Rawls menjelaskan bahwa para pihak di dalam posisi asali masing-masing akan mengadopsi dua prinsip keadilan utama. Prinsip pertama disebut "prinsip kebebasan yang sama" atau equal liberty principle, dimana setiap orang memiliki hak yang sama atas kebebasan-kebebasan dasar yang paling luas dan kompatibel

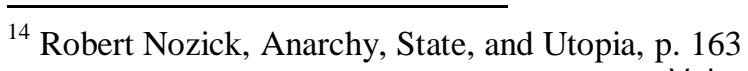


Website : http://yustisia.unmermadiun.ac.id/index.php/yustisia

dengan kebebasan-kebebasan sejenis bagi orang lain. Prinsip kedua disebut (a) "prinsip perbedaan" atau difference principle dan (b) prinsip persamaan kesempatan" equal opportunity principle, ketidaksamaan sosial dan ekonomi diatur sedemikian rupa, sehingga: (a) diperoleh manfaat sebesar-besarnya bagi anggota masyarakat yang paling tidak diuntungkan, dan (b) jabatan-jabatan dan posisi-posisi harus dibuka bagi semua orang dalam keadaan dimana adanya persamaan kesempatan yang adil. Sementara John Locke dalam karangannya membahas kemauan hidup bersama demi terpenuhi kebutuhan dan kepentingan bersama (social contract) .juga Rousseau dengan kemauan melakukan "kebaikan" pada orang lain tanpa tendensi apapun melainkan karena seluruh arah mata ingin melakukannya (categorical imperative), sesuai dengan aturan formal, dari Kant. ${ }^{15}$

Libertarianisme yang dikenal dengan bentuk yang dipersopan dari anarkis, memiliki pengertian yang sangat berbeda atau sekurang-kurangnya telah melanggar prinsip-prinsip sektor keadilan yang dikemukakan para filsuf.Sementara libertarianisme yang acuh tentang keadilan dalam hal kewajibannya terhadap negara dan orang lain, Indonesia justru sebaliknya. Sebagai negara yang menjunjung tinggi keadilan melalui salah satu sila Pancasila yang berbasis keadilan khusunya sila ke-2 dan sila ke-5, yaitu "kemanusiaan yang adil dan beradab, serta keadilan sosial bagi seluruh rakyat Indonesia", Indonesia mengakui adanya hak dan kewajiban yang harus dihormati serta dipatuhi oleh warga negaranya. Kedua sila tersebut mengandung budi luhur yang merupakan jati diri bangsa

Indonesia yaitu gotong-royong dan kekeluargaan selaras dengan semboyan negara yaitu "Bhineka Tunggal Ika" yang memiliki makna : walaupun berbeda-beda namun tetap satu.

Tentu libertarianisme sangat tidak sejalur dengan apa yang dianut dan dijalankan Indonesia. Sikap libertarian terkait ke-acuh-an mengenai peran negara dan hak serta kewajibannya terhadap orang lain adalah keegoisan dalam kacamata Pancasila. Meski hal tersebut akan mempercepat pembangunan dengan ketatnya daya saing setiap individu, namun bukan tidak mungkin hal tersebut akan menimbulkan kekacauan yang sangat kronis mengingat akan resiko saling menjatuhkan sangat tinggi. Belum lagi dengan resiko persaingan tidak sehat yang mungkin timbul akibat diberlakukannya pasar bebas yang dijunjung tinggi oleh kaum libertarianisme.

\section{PENUTUP}

\section{Kesimpulan}

Falsafah libertarianisme timbul akibat kritik atas sentralisasi ekonomi dan politik, untuk mengembalikan semangat gerakan sosial yang kurang beradap serta mengadopsi pola-pola sentralistik kapitalisme dan negara. Istilah libertarian dalam gerakan radikal diperkenalkan pertama kali di tahun 1858 oleh seorang anarkis berkebangsaan Perancis, Joseph Déjacque. pada tahun 80-an, partai sayap Kanan di Amerika mulai mengadopsi dan mendistorsi istilah libertarian untuk menggambarkan politik free market capitalis.

Libertarian menganggap bahwa setiap individu memiliki hak dan kebebasan penuh untuk mengkontrol segala sesuatu yang berhubungan dengan kehidupan mereka. Libertarian tidak mengakui peran negara sebagai pendikte arah dan tujuan hidup dengan segala aturan dan perangkatnya, namun mereka mendukung peran "negara minimal" dimana negara hanya bertugas memastikan keadilan tidak disalahgunakan dan tidak merugikan pihak lain, serta hak mampu terdistribusikan dengan baik tanpa adanya kerumpangan melalui : penegakan hukum dan sistem peradilan. Libertarian berkeyakinan bahwa jika pemerintah dalam konteks negara merupakan pemegang kendali kehidupan masyarakat, maka akan terjadi diskriminasi hak.

Libertarian hidup dengan cara mereka sendiri,sesuai dengan kemauan mereka sendiri, dengan pandangan hidup terhadap masyarakat yang bersifat suka rela dan seperlunya, selama hal tersebut mereka anggap tidak mengakibatkan pelanggaran hak untuk orang lain dengan meminimalkan peran pemerintah dan memaksimalkan kebebasan setiap individu. libertarian menolak adanya kewajiban yang bersifat sosial seperti pembayaran pajak, atau program pembiayaan bagi orang yang kurang beruntung dan subsidi. Itu berarti bahwa libertarian tidak mengharuskan orang lain menerima atas apa yang dimiliki orang lain, dan mereka juga berkeyakinan bahwa pemerintah tidak "berhak" memaksa mereka untuk membantu orang lain walaupun itu beralasan menyamaratakan keadilan sosial.

Libertarianisme yang dikenal dengan bentuk yang dipersopan dari anarkis, memiliki pengertian yang sangat berbeda atau sekurang-kurangnya telah melanggar prinsip-prinsip sektor keadilan yang dikemukakan para filsuf. Indonesia mengakui adanya hak dan kewajiban yang harus dihormati serta dipatuhi oleh warga negaranya. Ini tercermin dari sila ke-2 dan ke-5 Pancasila yang mengandung budi luhur yang merupakan jati diri bangsa Indonesia yaitu gotong-royong dan kekeluargaan selaras dengan semboyan negara yaitu "Bhineka Tunggal Ika" yang memiliki makna : walaupun berbeda-beda namun tetap satu. Tentu hal itu sangat tidak sejalur dengan apa yang dianut dan dijalankan Indonesia. Sikap libertarian terkait ke-acuh-an mengenai peran negara dan hak serta kewajibannya terhadap orang lain adalah keegoisan dalam kacamata Pancasila.

$\overline{{ }^{15} \text { http://indri-darwis.blogspot.com/2011/11/konsep-keadilan.html }}$

Volume 4 Nomor 2 September 2018, YUSTISIA MERDEKA | 109 


\section{Website : http://yustisia.unmermadiun.ac.id/index.php/yustisia}

\section{Rekomendasi}

Terlepas dari segala pro-kontra yang menyelubungi libertarianisme, pendiri bangsa Indonesia telah menegaskan bahwa diri Indonesia tidak sepantasnya meniru segala bentuk kelakuan buruk dan paham negaranegara barat. Karena Indonesia dibangun dengan asa gotong-royong dan kekeluargaan. Hal tersebut akan mungkin runtuh dengan sendirinya apabila kita mengikuti sifat-sifat radikal dari bangsa lain. Untuk itu, alangkah baiknya kita sebagai bangsa yang berperikemanusiaan yang bertujuan menciptakan kemanusiaan yang adil dan beradab serta keadilan sosial bagi seluruh rakyat Indonesia, hendaknya mengilhami peran bersama untuk menciptakan hal tersebut.

\section{E. DAFTAR PUSTAKA}

Boaz,David. 1998. “Libertarianism: A Primer”. New York: The Free Press.

Nozick, Robert. 1974. "Anarchy, State, and Utopia”. Amerika Serikat : Basic Books.

Rawls,John. 1971. “A Theory of Justice” Amerika Serikat : Harvard University Press.

Woodcock, George. 2004. “Anarchism: A History Of Libertarian Ideas And Movements”. Peterborough, Ont.: Broadview Press.

"Konsep Keadilan"

http://indri-darwis.blogspot.com/2011/11/konsep-keadilan.html/ Oleh Indriani Darwis dimuat pada Selasa, 01 November 2011

"Libertarianisme"

https://id.wikipedia.org/wiki/Libertarianisme/ Oleh Wikipedia bahasa Indonesia, ensiklopedia bebas terakhir diubah pada 3 November 2016

"Libertarianisme: Kebebasan, Hak, dan Keadilan"

https://indeks.or.id/2016/12/09/libertarianisme-kebebasan-hak-dan-keadilan/ Oleh Nanang Sunandar dimuat pada 9 Desember 2016

"Mengusulkan Sosialisme Libertarian"

https://perhimpunanmerdeka.wordpress.com/2015/06/15/mengusulkan-sosialisme-libertarian/ Oleh Titin Jayalangkara dimuat pada 15 Juni 2015

"Pengertian Keadilan dan Macam-Macam Keadilan"

http://www.artikelsiana.com/2015/01/pengertian-keadilan-macam-macam-keadilan.html/ dimuat pada Januari 2015

"Pengertian Keadilan Menurut Para Ahli dan Secara Umum Beserta Macam Macam Keadilan"

https://www.zonareferensi.com/pengertian-keadilan/ Oleh Zakky dimuat pada 28 Juli 2018

"Pengertian Keadilan Sosial : Makna dan Contohnya"

https://jagad.id/pengertian-keadilan-sosial-makna-dan-contohnya// Oleh Adam Muiz

"Platform Organisasi Komunis Libertarian (Draft)"

https://www.anarkismo.net/article/9309/ dimuat pada 7 Juli 2008

"The isms of the week: Liberalism and Libertarianism"

https://www.economist.com/johnson/2010/10/08/the-isms-of-the-week-liberalism-and-libertarianism/ Oleh Johnson dimuat pada 8 Oktober 2010

"Whai Is Libertarian?"

https://theihs.org/who-we-are/what-is-libertarian// 